\title{
IADS, a Decomposition Product of DIDS Activates a Cation Conductance in Xenopus Oocytes and Human Erythrocytes: New Compound for the Diagnosis of Cystic Fibrosis
}

\author{
Astrid Stumpf ${ }^{1}$, Joana Almaca ${ }^{2}$, Karl Kunzelmann², Kerstin Wenners- \\ Epping ${ }^{1}$, Stephan M. Huber ${ }^{4}$, Johannes Haberle ${ }^{3}$, Sabine Falk ${ }^{3}$, \\ Angelika Duebbers ${ }^{3}$, Mike Walte ${ }^{1}$, Hans Oberleithner ${ }^{1}$ and Hermann \\ Schillers $^{1}$
}

${ }^{1}$ Institute of Physiology II, University of Münster, ${ }^{2}$ Institute of Physiologie, University Regensburg, ${ }^{3}$ Department Pediatrics, University Hospitals of Münster, ${ }^{4}$ Department of Physiology I, University of Tübingen

\author{
Key Words \\ CFTR • Hydrolysis $・$ Hemolysis $•$ Gadolinium
}

\begin{abstract}
DIDS (4,4'-diisothiocyanato-stilbene-2,2'-disulfonic acid) is a commonly used blocker of plasma membrane anion channels and transporters. We observed that DIDS undergoes decomposition while stored in DMSO (dimethyl sulfoxide) forming a biologically active compound. One decomposition product, called IADS, was identified and synthesized. Voltage-clamp and patch clamp experiments on Xenopus laevis oocytes and human erythrocytes revealed that IADS is able to activate a plasma membrane cation conductance in both cell types. Furthermore, we found that IADS induces hemolysis in red blood cells of healthy donors but fails to hemolyze erythrocytes of
\end{abstract}

\section{KARGER}

Fax +4161306 1234

E-Mail karger@karger.ch

www.karger.com

\author{
(C) 2006 S. Karger AG, Basel \\ 1015-8987/06/0185-0243\$23.50/0

donors with cystic fibrosis. Thus, IADS stimulated activation of a cation conductance could form the basis for a novel diagnostic test of cystic fibrosis.

Copyright $\odot 2006$ S. Karger AG, Basel

\section{Introduction}

DIDS (4,4'-diisothiocyanato-stilbene-2,2'-disulfonic acid), a stilbene derivative, known to block chloride/bicarbonate exchange in human erythrocytes $[1,2]$, is commonly used in cellular research on cystic fibrosis (CF). $\mathrm{CF}$ is the most common congenital disease in Caucasians characterized by an impaired salt and fluid balance of epithelial cells. It is caused by a defective protein, the cystic fibrosis transmembrane conductance regulator (CFTR) [3]. The role of CFTR in erythrocytes is not fully understood although its presence in erythrocyte

\footnotetext{
Dr. Hermann Schillers

Institute of Physiology II

Robert-Koch-Str. 27b, D-48149 Münster (Germany)

Tel. +49 2518355 327, Fax +49 2518355331

E-Mail schille@uni-muenster.de
} 
membranes was clearly demonstrated in studies on CFTR dependent ATP release [4], plasmodium falciparum induced channel activation [5] and by western blots [6]. These findings have formed the basis of a functional blood test for CF diagnosis as recently reported [7].

By accident, we observed that when initially fresh DIDS is stored as a $100 \mathrm{mM}$ stock solution in DMSO at $4^{\circ} \mathrm{C}$ for two weeks or more and then used for experiments, significant hemolysis occurs in vitro. More surprisingly, this 'aged' DIDS fails to induce hemolysis of erythrocytes obtained from CF patients. We could not reproduce this effect with freshly prepared DIDS and thus assumed that not DIDS itself caused hemolysis but rather an unknown decomposition product. DIDS is a widely used blocker for plasma membrane anion exchangers and chloride channels [8]. In Addition, a number of other intriguing effects have been reported. It was shown that DIDS activates a cation conductance in $X$. laevis oocytes [9], blocks the tetrodotoxin-sensitive $\mathrm{Na}^{+}$channel of cardiac myocytes [10], stimulates $\mathrm{Ca}^{2+}$-induced $\mathrm{Ca}^{2+}$-release mechanism [11] in muscle cells, modifies the channel properties of the cardiac ryanodine receptor [12], stimulates phosphatase activity of the erythrocyte membrane $\mathrm{Ca}^{2+}$-ATPase[13] and blocks ATP-sensitive $\mathrm{K}^{+}$channels [14]. Due to the diversity of the observed DIDS actions we assumed that probably some of these effects could have been caused by a yet unidentified DIDS decomposition product. The most likely decomposition of DIDS is the hydrolysis of one isothiocyanato group [15] resulting in 4-isothiocyanato-4'-amino-stilbene-2,2'disulfonic acid (scheme 1). We named this substance IADS. We synthesized IADS and tested it in electrophysiological experiments using erythrocytes and Xenopus oocytes. Furthermore, we tested IADS in erythrocytes of healthy donors and patients with cystic fibrosis (CF).

\section{Materials and Methods}

Synthesis of 4-isothiocyanato-4'-amino-stilbene-2,2'disulfonic acid (IADS)

The synthesis was modified according to the method of Maddy [15]. In short, 2.24 g 4,4'-diamino-stilbene-2,2'-disulfonic acid (DADS) was dissolved in $20 \mathrm{ml}$ of ice-cold $1 \% \mathrm{NaCl}(\mathrm{w} / \mathrm{v})$ (final concentration $5.4 \mathrm{mM}$ ). An equimolar amount of thiophosgene $(0.42 \mathrm{ml})$ was added and the mixture stirred for 90 $\min$ at $4^{\circ} \mathrm{C}$. The precipitate, 4 -isothiocyanato-4'-amino-stilbene2,2'-disulfonic acid (IADS), was filtered and washed three times with ice-cold $1 \% \mathrm{NaCl}$. The 4-isothiocyanato-4'-amino-stilbene2,2'-disulfonic acid became water soluble after titration with $\mathrm{NaOH}$ to $\mathrm{pH} 7.0$.

\section{Blood samples}

Freshly drawn venous blood was used from healthy volunteers and from patients with the homozygous $\Delta \mathrm{F} 508$ mutation. A consensus statement according to the declaration of Helsinki was signed from all blood donors. The ethics committee of the General Medical Council 'Westfalen-Lippe' approved the experiments (07/09/2004, Reg-No. 4VII Schillers). The number of tested individuals is indicated by ' $n$ '.

\section{Xenopus laevis oocytes}

Experiments were performed in Xenopus laevis oocytes, stage VI, obtained as described[16] and stored in ND96 buffer (in mM: $96 \mathrm{NaCl}, 2 \mathrm{KCl}, 1.8 \mathrm{CaCl}_{2} \cdot 2 \mathrm{H}_{2} \mathrm{O}, 1 \mathrm{MgCl}_{2} \cdot 6 \mathrm{H}_{2} \mathrm{O}, 5 \mathrm{HEPES}$, 2.5 sodium pyruvate, adjusted to $\mathrm{pH} 7.5$ with $\mathrm{NaOH}$ ). The medium contained $100 \mathrm{IU} / \mathrm{mL}$ penicillin and $100 \mathrm{mg} / \mathrm{ml}$ streptomycin). Oocytes were defolliculated prior to voltage clamp experiments by a 1 hour treatment with $1 \mathrm{mg} / \mathrm{ml}$ collagenase (type D, Boehringer Mannheim) [17].

\section{Double electrode voltage-clamp}

Oocytes were impaled with two electrodes which had a resistances of $<1 \mathrm{M} \Omega$ when filled with $2.7 \mathrm{mM} \mathrm{KCI}$. Using two bath electrodes and a virtual-ground head stage, the voltage drop across $\mathrm{R}_{\text {serial }}$ was effectively zero. Membrane currents were measured by voltage-clamping of the oocytes (Warner oocyte clamp amplifier OC725C) in intervals from -90 to $+30 \mathrm{mV}$, in steps of $10 \mathrm{mV}$, each $1 \mathrm{~s}$. IADS was added to the bath solution at a concentration of $30 \mu \mathrm{M}$. Experiments with impermeable cations were performed in NMDG (N-methyl-D-glucamine-Cl ) buffer (in mM: NMDG, 96; $\mathrm{HCl}, 80 ; \mathrm{KCl}, 2 ; \mathrm{CaCl}_{2}, 1.8 ; \mathrm{MgCl}_{2}, 1$; HEPES, 5; sodium pyruvate, 2.5; pH 7.55). For $\mathrm{Ca}^{2+}$ free conditions, $\mathrm{CaCl}_{2}$ was omitted and $5 \mathrm{mM}$ EGTA (ethylene glycolbis (aminoethyl ether)-N,N,N',N'-tetraacetic acid) was added to the bath solution. During the whole experiment, the bath was continuously perfused at a rate of $5-10 \mathrm{ml} / \mathrm{min}$. All experiments were conducted at room temperature $\left(22{ }^{\circ} \mathrm{C}\right)$.

\section{Patch clamp of erythrocytes}

Patch clamp experiments have been performed at room temperature in voltage-clamp, fast-whole-cell mode according to Hamill et al. [18] The cells were continuously superfused through a flow system inserted into the dish. The bath was grounded via a bridge filled with $\mathrm{NaCl}$ solution. Borosilicate glass pipettes (8-12 M tip resistance; GC $150 \mathrm{TF}-10$, Clark Medical Instruments, Pangbourne, UK) manufactured by a microprocessor-driven DMZ puller (Zeitz, Augsburg, Germany) were used in combination with a MS314 electrical micromanipulator (MW, Märzhäuser, Wetzlar, Germany). The currents were recorded by an EPC-9 amplifier (Heka, Lambrecht, Germany) using Pulse software (Heka) and an ITC-16 Interface (Instrutech, Port Washington, N.Y., USA). Whole-cell currents were determined at eleven successive 400-ms square pulses from the $-30 \mathrm{mV}$ holding potential to potentials between -100 $\mathrm{mV}$ and $+80 \mathrm{mV}$. The current values were $3 \mathrm{kHz}$ low-pass filtered. Currents of the individual voltage square pulses are superimposed in the current traces depicted in Fig. 2A. The applied voltages refer to the cytoplasmic face of the membrane with respect to the extracellular space. The inward currents,

Stumpf/Almaca/Kunzelmann/Wenners-Epping/Huber/Haberle/Falk/ Duebbers/Walte/Oberleithner/Schillers 
Fig. 1. The stilbene derivative, IADS, activates an electrical current in Xenopus laevis oocytes. Current trace of IADS application in ND96 buffer (A) and NMDG-Cl (B). Mean current-voltage relationships recorded in voltage-clamp experiments before (open circles) and during application of $30 \mu \mathrm{M}$ IADS (closed circles) in ND96 buffer (C) and NMDG-Cl (D). Mean whole cell membrane conductance, as calculated from the data in $\mathrm{C}$ (E) and D (F) using linear regression of the electrical current values between -60 and +40 $\mathrm{mV}$ voltage $(*: \mathrm{p}<0.01$; student's t-test;).

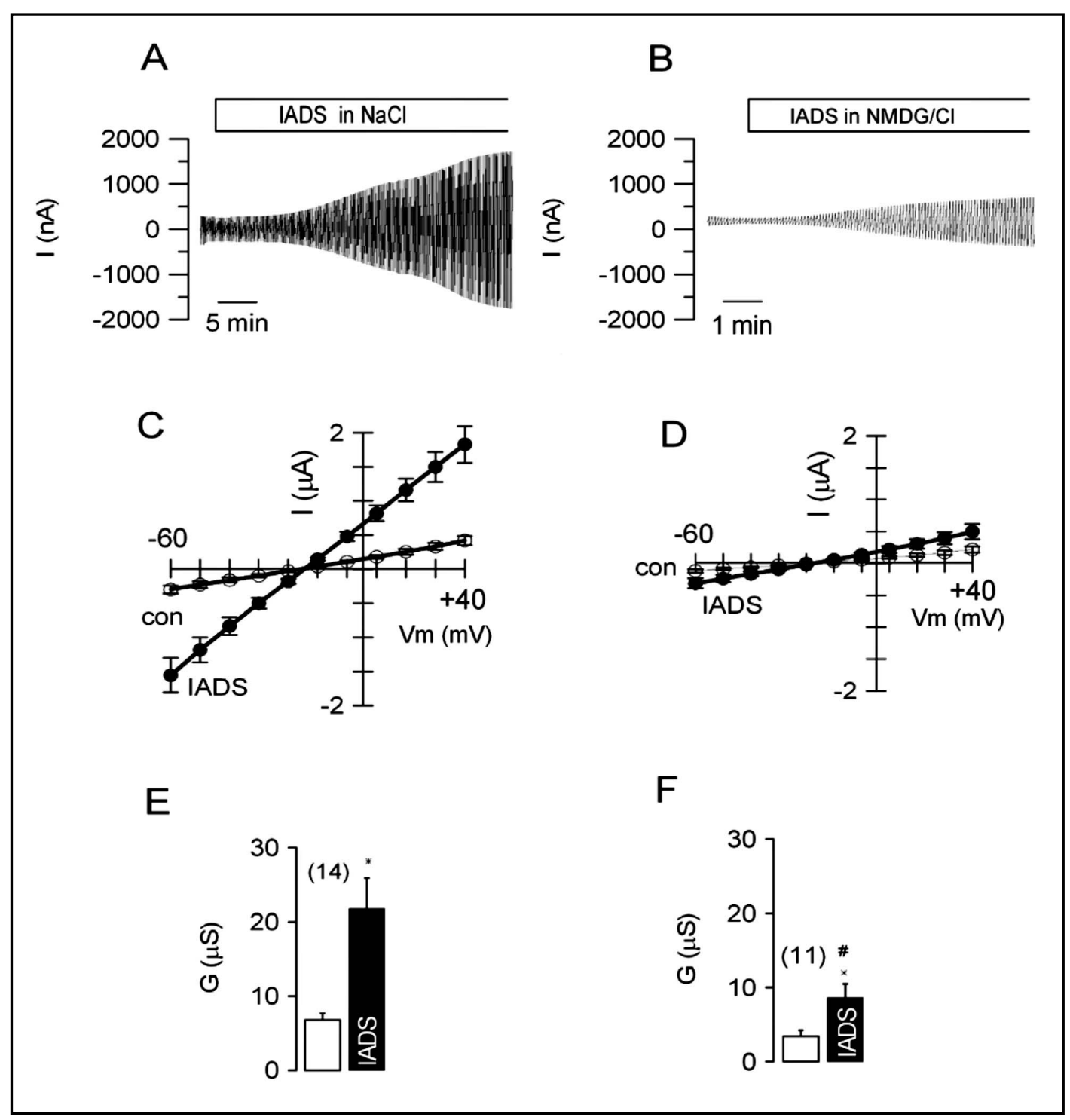

defined as flow of positive charge from the extracellular to the cytoplasmic membrane face, are negative currents and depicted as downward deflections of the current traces. The offset potentials between both electrodes were zeroed before sealing. The potentials were corrected for liquid junction potentials as estimated according to Barry and Lynch [19].

A Na-gluconate pipette solution (containing in mM: 80 $\mathrm{KCl}, 60 \mathrm{~K}$-gluconate, $10 \mathrm{HEPES} / \mathrm{KOH}, 1$ EGTA, $1 \mathrm{Mg}$-ATP, 1 $\mathrm{MgCl}_{2} ; \mathrm{pH}$ 7.2) was used in combination with $\mathrm{NaCl}$ (containing in mM: $115 \mathrm{NaCl}, 10 \mathrm{MgCl}_{2}, 5 \mathrm{CaCl}_{2} ; 20 \mathrm{HEPES} / \mathrm{NaOH}, \mathrm{pH} 7.4$ ) or NMDG-Cl bath solution (containing in mM: $160 \mathrm{~N}$-methyl-Dglucamine-Cl (NMDG-Cl), 10 HEPES/NMDG; pH 7.4). The stilbene derivate IADS was added to the bath solution at a concentration of $30 \mu \mathrm{M}$.

\section{Hemolysis measurements}

Venous blood from healthy donors and cystic fibrosis (CF) patients with the homozygous $\Delta \mathrm{F} 508$ mutation was freshly drawn in $\mathrm{K}_{2}$-EDTA Monovettes (Sarstedt, Germany) and cen- trifuged for $10 \mathrm{~min}$ at $1000 \mathrm{~g}$. Supernatant and buffy coat were removed and erythrocytes washed two times in a 2-fold volume of a solution containing $155 \mathrm{mM} \mathrm{NaCl}, 10 \mathrm{mM}$ Hepes; $\mathrm{pH}$ 7.4. $50 \mu \mathrm{l}$ of washed erythrocytes were resuspended in $450 \mu \mathrm{l}$ of $155 \mathrm{mM} \mathrm{KCl}, 10 \mathrm{mM}$ HEPES; $\mathrm{pH} 7.4$ (hematocrit 0.1). This suspension was incubated at $37^{\circ} \mathrm{C}$ in a bacteria shaker at $280 \mathrm{rpm}$ for $60 \mathrm{~min}$. We decided to incubate erythrocytes for $60 \mathrm{~min}$ since hemolysis, at this time point, reaches values sufficient to distinguish between non-CF and $\mathrm{CF}$ erythrocytes. Thereafter, the suspension was centrifuged at $2000 \mathrm{~g}$ for $5 \mathrm{~min}$ and 'free' hemoglobin in the supernatant was quantified by optical density measurements at $546 \mathrm{~nm}$ (OD546). Results were correlated to $100 \%$ hemolysis to avoid errors elicited by the individual scatter of different mean corpuscular hemoglobin content (MCHC). For each blood sample we lysed $50 \mu \mathrm{l}$ washed erythrocytes in $450 \mu \mathrm{l} \mathrm{H}_{2} \mathrm{O}$ (the optical density of this solution represents $100 \%$ hemolysis) and made a calibration curve with appropriate dilutions.

Cell Physiol Biochem 2006;18:243-252 


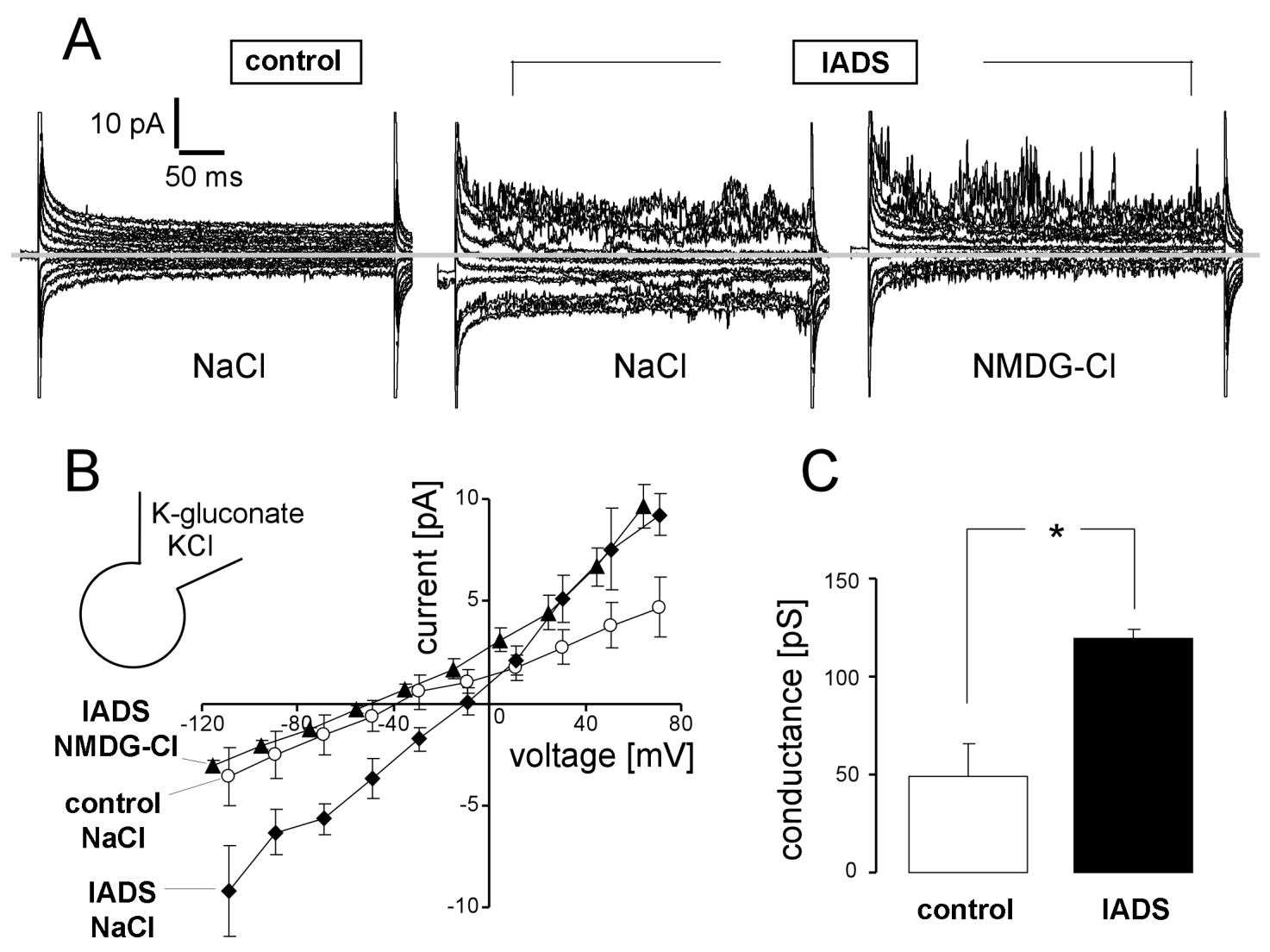

Fig. 2. IADS stimulates a cation current in human erythrocytes of healthy donors. (A) Electrical current traces recorded in whole cell configuration from a human erythrocyte before (left) and during stimulation with IADS (30 $\mu$ M; middle and right). Electrical currents were recorded with $\mathrm{KCl} / \mathrm{K}$-gluconate in the pipette and either $\mathrm{NaCl}$ (left and middle) or NMDG-Cl as bath solution (right). The zero current is indicated by the grey line. (B) Mean current-voltage relationships recorded as in (A), under control conditions (open circles) and, during stimulation with IADS (30 $\mu \mathrm{M}$; closed symbols). Stimulated cells were bathed in either $\mathrm{NaCl}$ (closed diamonds) or NMDG-Cl containing solution (closed triangles). (C) Mean whole cell conductance as calculated from the data in $\mathrm{B}$ (open circles and closed diamonds) using linear regression of the current values between +20 and $+80 \mathrm{mV}$ voltage $(*$ : $\mathrm{p}=0.05$; two-tailed Welch-corrected student's t-test).

\section{Chemicals}

All chemicals, unless otherwise mentioned, were purchased from Sigma (Deisenhofen, Germany). DADS was purchased from Acros Organics (Geel, Belgium), DIDS was purchased from different sources, namely from Molecular Probes (Eugene, OR, USA), from ICN Biomed (Irvine, CA, USA), from Acros organics (Geel, Belgium), from Sigma (Deisenhofen, Germany) and from Calbiochem (Bad Soden, Germany).

\section{Statistics}

All data are presented as mean \pm s.e.m.. Student's $t$-test $p$ values $<0.05$ were accepted to indicate statistical significance, with number $n$ of experiments given in parentheses. The erythrocytes of each blood donor were tested at least twice in hemolysis experiments.

\section{Results}

\section{Voltage clamp experiments in oocytes}

In ND96 buffer $X$. laevis oocytes exhibited a linear plasma membrane electrical conductance, with a slope conductance of $6.8 \pm 0.91 \mu \mathrm{S}$ ( $\mathrm{n}=14)$. Adding $30 \mu \mathrm{M}$ IADS increased the conductance by about three times, to 21.8 $\pm 4.14 \mu \mathrm{S}(\mathrm{n}=14)$ (Fig. 1A, C, E). The IADS-stimulated electrical current (i.e., the difference between the closed and open bar of Fig. 1 E) showed a slope conductance around $15.0 \pm 3.82 \mu \mathrm{S}(\mathrm{n}=14)$, with a reversal potential $\left(\mathrm{V}_{\text {rev }}\right)$ close to $-25 \mathrm{mV}$. Replacing $\mathrm{NaCl}$ in the bath solution with NMDG resulted in a conductance of $3.4 \pm 0.82$

Stumpf/Almaca/Kunzelmann/Wenners-Epping/Huber/Haberle/Falk/ Duebbers/Walte/Oberleithner/Schillers 
Fig. 3. Inhibition of IADS-induced hemolysis of non-CF erythrocytes. IADS-induced hemolysis was significantly reduced by either $100 \mu \mathrm{M}$ DIDS (black bar, $\mathrm{n}=19$ ), $100 \mu \mathrm{M} \mathrm{Gd} \mathrm{G}^{3+}$ (grey bar, $\mathrm{n}=36$ ) and $10 \mathrm{mM} \mathrm{Ba}{ }^{2+}$ (dark-grey bar, $n=14$ ). Substitution of the impermeable cation $\mathrm{NMDG}^{+}$for $\mathrm{K}^{+}$ abolishes IADS-induced hemolysis (hatched bar, $\mathrm{n}=15$ ). The black bar under the $\mathrm{x}$-axis indicates the presence of IADS during the experiments $(*: \mathrm{p}=0.01 ; * *: \mathrm{p}=0.05$; student's t-test).
Fig. 4. Concentrationresponse curve of IADSinduced hemolysis of non-CF erythrocytes. Data presented as mean $\pm \operatorname{sem}(\mathrm{n}=$ between 6 and 62 ; squares) with a Boltzmann fit (dashed line).
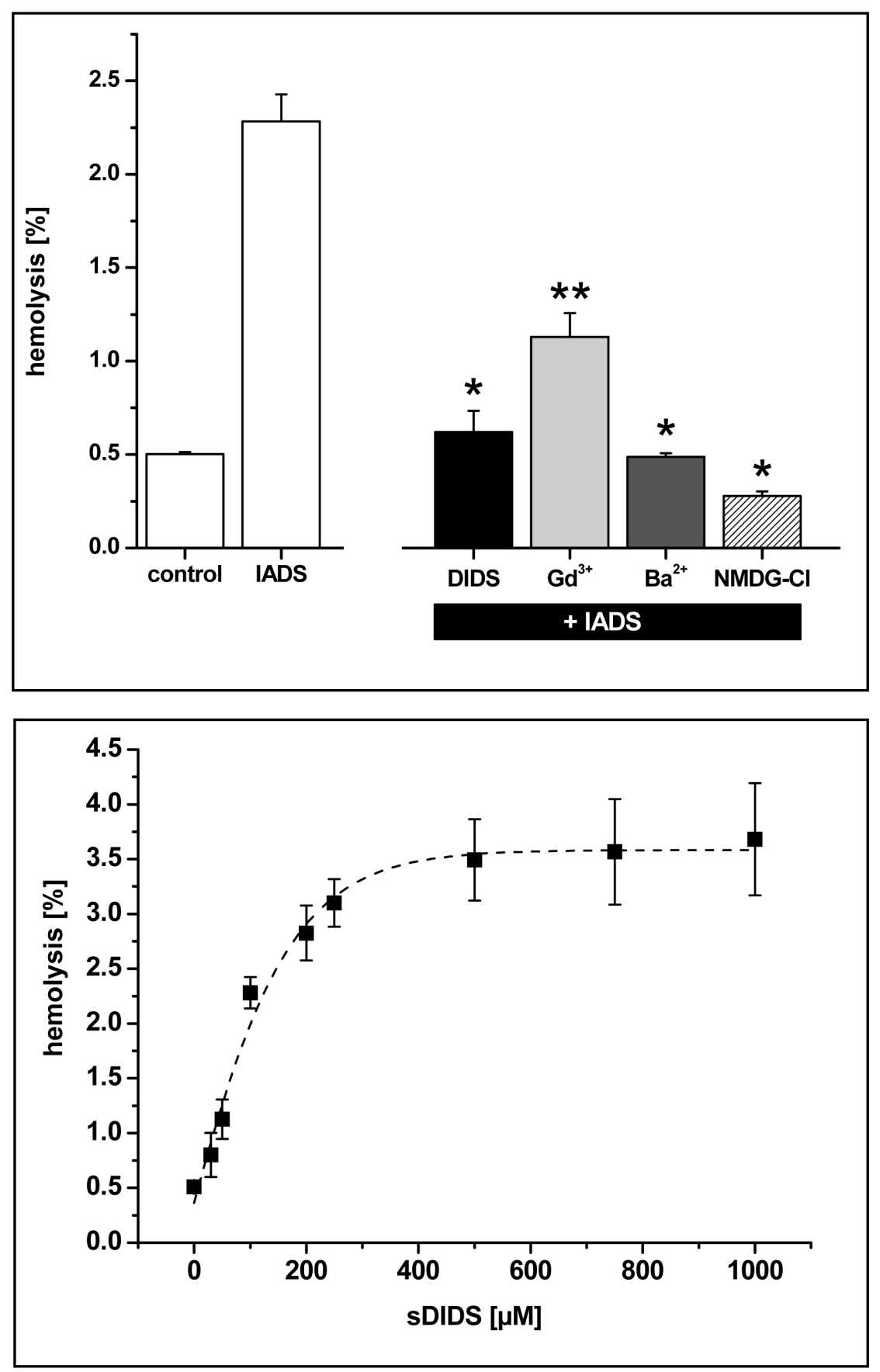

$\mu \mathrm{S}(\mathrm{n}=11)$ and $8.6 \pm 1.84 \mu \mathrm{S}(\mathrm{n}=11)$ with $30 \mu \mathrm{M}$ IADS (Fig. 1 B, D, F). In NMDG buffer, the IADS induced conductance was $5.2 \pm 1.50 \mu \mathrm{S}(\mathrm{n}=11)$, three times lower than in $\mathrm{NaCl}$ solution (the difference between the closed and open bar of Fig. $1 \mathrm{~F}$ ). In order to test whether the IADS stimulated conductance was a $\mathrm{Ca}^{2+}$ current, we added $5 \mathrm{mM}$ EGTA to the NMDG bath solution. There was no significant difference in IADS-stimulated conductance $(5.0 \pm 1.02 \mu \mathrm{S}, \mathrm{n}=11)$ by removing $\mathrm{Ca}^{2+}$ (data not shown).

IADS, a Biologically Active Decomposition Product of DIDS
Whole-cell patch-clamp experiments in erythrocytes

Patch-clamp studies were performed with $\mathrm{KCl}$ / $\mathrm{K}$-gluconate solution in the pipette, while the bath solution contained $\mathrm{NaCl}$ with high $\mathrm{MgCl}_{2}$ and $\mathrm{CaCl}_{2}$ concentrations in order to obtain high resistance seals. With these solutions, the whole-cell currents of human erythrocytes exhibited a conductance of $49 \pm 16 \mathrm{pS},(\mathrm{n}=3)$, as calculated for the outward current between +20 and $+80 \mathrm{mV}$ and a mean reversal potential $\left(\mathrm{V}_{\text {rev }}\right)$ of 
$-34 \pm 15 \mathrm{mV}$ (Fig. 2A left, 2B open circles and Fig. 2C open bar). Addition of IADS $(30 \mu \mathrm{M})$ to the $\mathrm{NaCl}$ bath solution increased within one minute whole-cell conductance to $119 \pm 5 \mathrm{pS}$ (Fig. 2A middle, and 2C closed bar). This conductance increase was accompanied by a shift of $\mathrm{V}_{\text {rev }}$ to $-10 \pm 7 \mathrm{mV}$ (Fig. 2B closed diamonds). The IADS-stimulated whole-cell current (i.e., the difference in Fig. 2B between the open circles and the closed diamonds) showed a $\mathrm{V}_{\text {rev }}$ close to $0 \mathrm{mV}$. This suggested a cation permeability. This cation permeability was further indicated by a shift of $\mathrm{V}_{\text {rev }}$ to $-48 \pm 5 \mathrm{mV}$ upon replacement of $\mathrm{Na}^{+}$in the bath by the impermeant cation $\mathrm{NMDG}^{+}$(Fig. 2A right and 2B, closed triangles).

\section{Hemolysis experiments in erythrocytes of healthy} donors and $C F$ patients

Incubation of erythrocytes in $\mathrm{KCl}$ buffer, with addition of $100 \mu \mathrm{M}$ IADS, led to hemolysis. Quantification by optical density measurements at $546 \mathrm{~nm}\left(\mathrm{OD}_{546}\right)$ revealed a hemolysis of $2.28 \pm 0.143 \%(n=62)$ while incubation of erythrocytes in $\mathrm{KCl}$ buffer without IADS (indicated as control) elicited only low values of hemolysis $(0.51 \pm 0.011 \%, \mathrm{n}=62)$ (Fig 3). The IADS-induced hemolysis was sensitive to $100 \mu \mathrm{M}$ DIDS $(0.62 \pm 0.114 \%$, $\mathrm{n}=19)$ (black bar), to $100 \mu \mathrm{M}$ gadolinium $\left(\mathrm{Gd}^{3+} ; 1.13 \pm\right.$ $0.128 \%, \mathrm{n}=36)$ (grey bar) and to $10 \mathrm{mM} \mathrm{Ba}^{2+}(0.49 \pm$ $0.019 \%, \mathrm{n}=14$; dark-grey bar). Substitution of the impermeable cation $\mathrm{NMDG}^{+}$for $\mathrm{K}^{+}$abolished IADS-induced hemolysis $(0.28 \pm 0.02 \%, \mathrm{n}=15$; hatched bar, Fig 3).

In order to test whether synthesis-derived impurities of the IADS preparation cause the observed hemolysis we applied both, the reactant of the IADS synthesis, 4,4'-diamino-2-2' stilbene disulfonanic acid (DADS), and the possible by-product 4,4'diisothiocyanato-stilbene-2,2'-disulfonic acid (DIDS). We observed that neither $1 \mathrm{mM}$ DADS nor $100 \mu \mathrm{M}$ DIDS was able to induce hemolysis of non-CF or CF erythrocytes (data not shown).

The influence of the IADS concentration on the hemolysis of non-CF erythrocytes was tested in the range of $30 \mu \mathrm{M}$ to $1000 \mu \mathrm{M}$. The sigmoidal (Boltzmann) fit of the mean values $(\mathrm{n}=$ between 6 and 62 ) resulted in a concentration - response curve with a half maximal IADS concentration of $\sim 85 \mu \mathrm{M}$ (Fig. 4).

As described above, IADS led toa significant hemolysis of human erythrocytes. However, erythrocytes from CF patients with the homozygous $\Delta \mathrm{F} 508$ mutation showed a strongly reduced rate of hemolysis under the same conditions (Fig. 5). Quantification revealed a

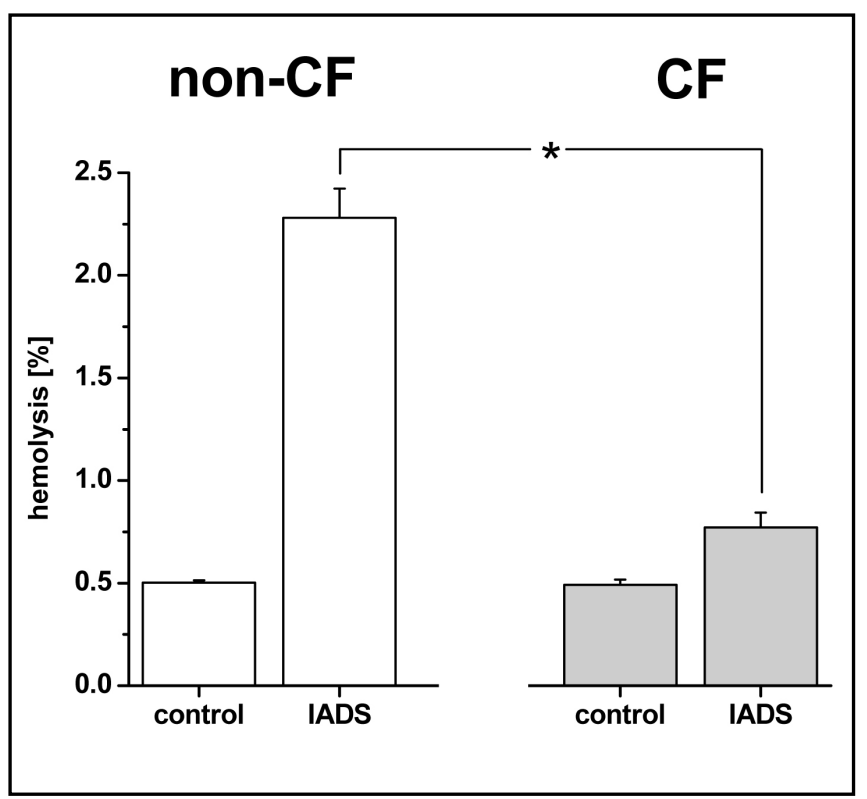

Fig. 5. IADS leads to hemolysis of erythrocytes obtained from healthy donors (non-CF, open bars, $n=62$ ) but fails to hemolyse erythrocytes of cystic fibrosis patients $(\mathrm{CF}$, grey bars, $n=41)$.

hemolysis of $2.28 \pm 0.143 \%$ ( $\mathrm{n}=62)$ for non-CF erythrocytes (open bars) and $0.77 \pm 0.072 \%(\mathrm{n}=41)$ for $\mathrm{CF}$ erythrocytes (grey bars). In absence of IADS the mean control values between non - CF and CF erythrocytes did not differ significantly $(0.51 \pm 0.011 \%, \mathrm{n}=62$ and $0.52 \pm 0.012 \%, \mathrm{n}=41$, respectively).

\section{Discussion}

The plasma membrane ion transport inhibitor DIDS is commercially available from several companies and the appearance of the compound varies from nearly colourless over yellow to orange. Obviously, most of the DIDS preparations contain impurities caused by the synthesis procedure. DIDS is a disulfonic stilbene derivative with two reactive isothiocyanate groups. Usually, DIDS is dissolved and stored as stock solution in DMSO. We noticed a $\mathrm{H}_{2} \mathrm{~S}$ smell of the DIDS stock solution when stored for two weeks in DMSO and concluded that some hydrolysis of an isothiocyanate group had occurred. Commercially available DMSO contains up to $3 \%(\mathrm{w} / \mathrm{v})$ water and this is sufficient to induce hydrolysis of the isothiocyanate groups. As a result, $\mathrm{CO}_{2}, \mathrm{H}_{2} \mathrm{~S}$ and 4isothiocyanato-4'-amino-stilbene-2,2'-disulfonic acid are generated (scheme 1). Additionally, amino groups can react with isothiocyanate groups to form $\mathrm{N}$-substituted

Stumpf/Almaca/Kunzelmann/Wenners-Epping/Huber/Haberle/Falk/ Duebbers/Walte/Oberleithner/Schillers 


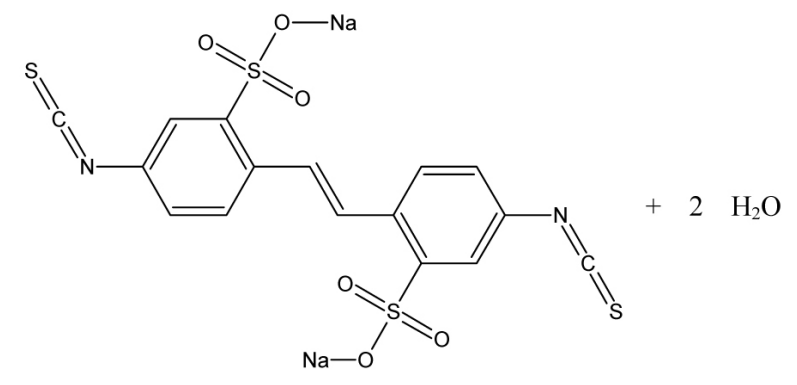

DIDS

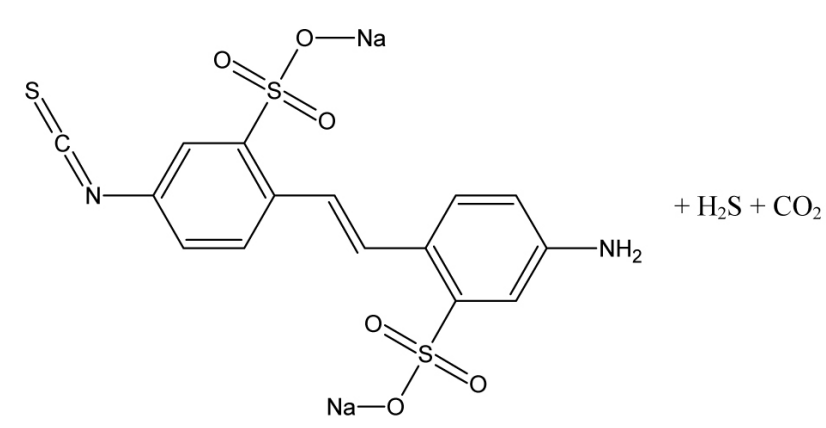

IADS

Scheme 1. Partial hydrolysis of DIDS resulting in 4-isothiocyanato-4'-amino-stilbene-2,2'-disulfonic acid (IADS), hydrogen sulphide and carbon dioxide.

Scheme 2. Scheme of the proposed mechanism of the IADS-induced hemolysis.

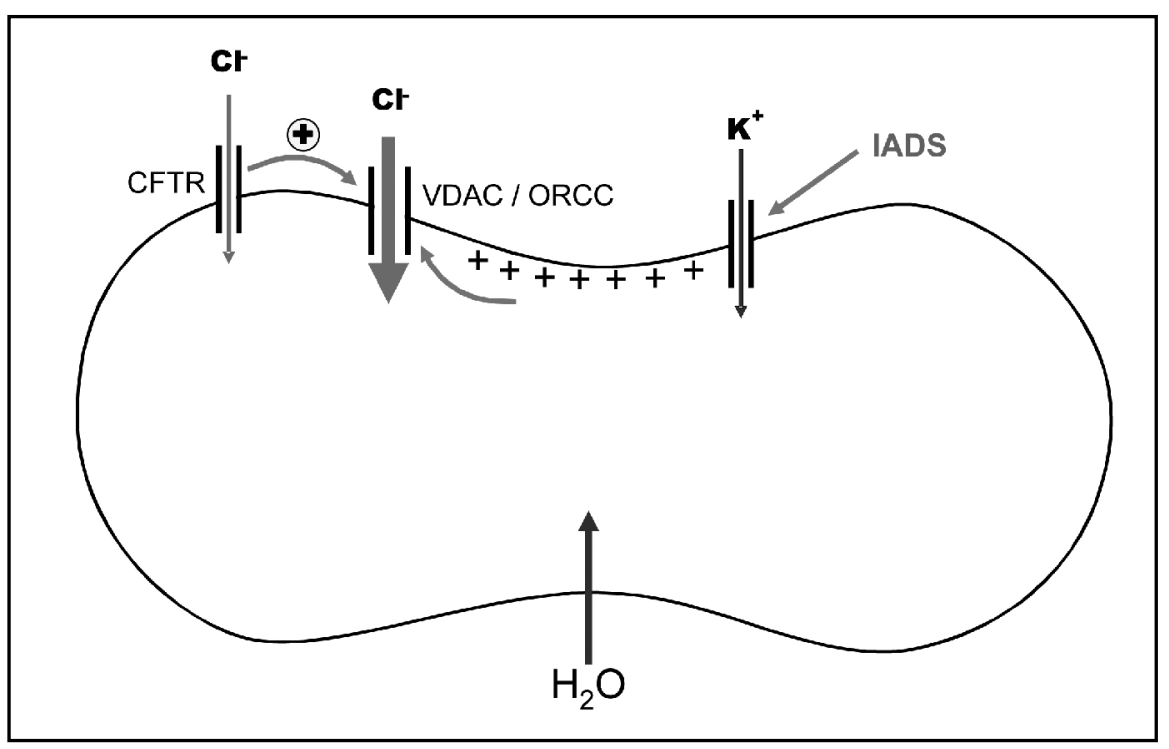

intact when exposed to DIDS. Since we realized that DIDS has been obviously decomposed at the time of usage, we decided to identify and synthesize the active decomposition product and to test it in electrophysiological experiments.

First, we tested IADS in oocytes since Diakov et al. [9] reported a DIDS-activated cation conductance in this cell type. They used $250 \mu \mathrm{M}$ DIDS to activate these channels. Assuming that 'their' DIDS was partially decomposed, we applied a lower concentration of IADS $(30 \mu \mathrm{M})$ and, indeed, observed channel activation. Channel activation, however, occurred already at concentrations as low as $1 \mu \mathrm{M}$ (data not shown). $30 \mu \mathrm{M}$ of IADS was sufficient to activate a (poorly reversible) cation current in human erythrocytes. Replacing the $\mathrm{NaCl}$

Cell Physiol Biochem 2006;18:243-252 
bath solution with NMDG-Cl solution resulted in a decrease of electrical plasma membrane conductance in Xenopus oocytes as well as in human erythrocytes indicating that the channels were selective for cations. The conductance was not $\mathrm{Ca}^{2+}$ mediated as experiments in ooyctes with $\mathrm{Ca}^{2+}$ free conditions show. The activation of this channel led to hemolysis of erythrocytes when incubated in $\mathrm{KCl}$. We realized that a higher concentration of IADS was necessary to induce hemolysis than to activate the channels. We achieved hemolysis of about $0.8 \%$ with $30 \mu \mathrm{M}$ IADS (Fig. 4), a low but detectable value of hemolysis. Experiments with $100 \mu \mathrm{M}$ IADS resulted in a hemolysis of about $2.3 \%$ which was already detectable by visual check. Testing different IADS concentrations in the range of $30 \mu \mathrm{M}$ to $1000 \mu \mathrm{M}$ revealed that maximal hemolysis value was $3.58 \%$ with a halfmaximal IADS concentration of $85 \mu \mathrm{M}$. Although IADSinduced hemolysis of non-CF erythrocytes was clearly detectable, only about $3.58 \%$ of all erythrocytes were lysed. From this observation we derive that most likely a minor population of erythrocytes responds to IADS. We presume that reticulocytes and very young erythrocytes are the potential candidates. Indeed, during erythrogenesis plasma membrane transporters rarify over time [21]. Possibly, also CFTR diminishes during maturation.

Due to the IADS synthesis procedure, it is possible that the final IADS preparation contains impurities as the reactant 4,4'-diamino-2-2' stilbene disulfonanic acid (DADS) and the product of the reaction of both amino groups, 4,4'-diisothiocyanato-stilbene-2,2'-disulfonic acid (DIDS). In order to test whether synthesis- derived impurities in the IADS preparation could cause the observed hemolysis we incubated erythrocytes with either DADS or DIDS in different concentrations. Neither $1 \mathrm{mM}$ DADS nor $100 \mu \mathrm{M}$ DIDS was able to induce hemolysis of non-CF or CF erythrocytes (data not shown). Taken together, the potential impurity products DADS and DIDS do not cause the observed hemolysis.

To further characterize IADS-induced hemolysis, we performed hemolysis experiments in NMDG-Cl containing solution. Consistent with the preceding experiments IADS failed to induce hemolysis when $\mathrm{K}^{+}$was substituted by the impermeable cation $\mathrm{NMDG}^{+}$, indicating that cation influx through the IADS-activated channel was a prerequisite for hemolysis. Duranton et al. [22] detected an oxidation-induced cation channel in erythrocytes that was sensitive to $\mathrm{Gd}^{3+}$ and that, in response to its activation, caused hemolysis due to cation influx, paralleled by anion and water uptake [22]. In agreement with these findings, IADS-induced hemolysis could be also reduced by $50 \%$ with $\mathrm{Gd}^{3+}(100 \mu \mathrm{M})$. These results indicate that both IADS and oxidation activate the same cation conductance in human erythrocytes.

It was reported that hyperosmotic shock, energy depletion or removal of extracellular $\mathrm{Cl}^{-}$activates $\mathrm{Ca}^{2+}$ permeable cation channels in erythrocyte membranes [23, 24]. In order to test whether the IADS-stimulated conductance in oocytes was based upon a $\mathrm{Ca}^{2+}$ current, we measured the IADS-activated current in NMDG bath solution without and with $5 \mathrm{mM}$ EGTA, a calcium chelating compound. We observed no reduction of the electrical current under $\mathrm{Ca}^{2+}$-free conditions. Therefore, it is likely that the IADS-induced conductance is not based upon the cation channels described above. Nevertheless, patch clamp studies on erythrocytes are necessary to clarify this question. Finally, we found that IADS-induced hemolysis is sensitive to barium ions indicating that the IADS-induced plasma membrane conductance is based on monovalent cations.

The influence of anion influx on IADS-induced hemolysis was tested with $100 \mu \mathrm{M}$ DIDS. This commonly used blocker for plasma membrane anion conductances indeed prevents hemolysis. In conclusion, we assume that the influx of cations, triggered by IADS-activatable plasma membrane channels, is paralleled by a DIDS-sensitive uptake of anions and water. This finally leads to the observed hemolysis.

Initially, we observed a difference in hemolysis between non-CF and CF erythrocytes after application of DIDS which was taken from a stock solution stored for two weeks. However, due to the ongoing decomposition of DIDS, hemolysis data were hardly reproducible. After identification and synthesis of the decomposition product, we could now apply IADS at a defined concentration $(100 \mu \mathrm{M})$. This enables to distinguish between non$\mathrm{CF}$ and CF erythrocytes by the degree of IADS-induced hemolysis.

It is likely that the observed hemolysis is triggered by $\mathrm{K}^{+}$influx through the IADS-activated cation channel. Erythrocytes, obtained from CF patients with the homozygous $\triangle F 508$ mutation, appear to be resistant against IADS-induced hemolysis by yet unknown mechanisms. It is known that various epithelial ion transport processes are typically affected in cystic fibrosis [3]. An increasing number of plasma membrane channels are known to be controlled by CFTR, e.g. inwardly rectifying $\mathrm{K}^{+}$channels [25], vertebrate transient receptor potential cationic channels (TRPV4) [26], ATP-inhibitable $\mathrm{K}^{+}$channels $\left(\mathrm{K}_{\text {ATP }}\right)$ [27], epithelial sodium channels $(\mathrm{ENaC})[28,29]$ but also anion channels, e.g. outwardly rectifying chlo-

Stumpf/Almaca/Kunzelmann/Wenners-Epping/Huber/Haberle/Falk/ Duebbers/Walte/Oberleithner/Schillers 
ride channels (ORCC) [30], calcium activated chloride channels $(\mathrm{CaCC})$ [31], volume-regulated anion channels (VRAC) [32] and voltage-dependent $\mathrm{Cl}^{-}$channels (ClC3B) $[33,34]$. Most likely, a CFTR-controlled and DIDSsensitive anion channel is essential for IADS-induced hemolysis. This anion channel maintains $\mathrm{Cl}^{-}$uptake, when $\mathrm{K}^{+}$influx is triggered by the IADS-activated plasma membrane cation conductance. A possible candidate is the voltage dependent anion channel, VDAC [35], which is assumed to be a part of the DIDS sensitive, CFTR-controlled ORCC [36]. In this case, influx of cations through the IADS-activated channel should depolarize the membrane and, thus, stimulate VDAC [37] (scheme 2). Erythrocytes from $\mathrm{CF}$ patients show a reduced number of CFTR in plasma membrane [38]. Therefore, a lack of CFTR in erythrocyte plasma membrane of CF patients prevents IADS-mediated VDAC activation and, finally, salt and water uptake. A detailed clarification of the underlying mechanism of IADS-induced hemolysis is subjected to further investigations.

\section{Abbreviations}

CF (cystic fibrosis); DIDS (4,4'-diisothiocyanatostilbene-2,2'-disulfonic acid); IADS (4-isothiocyanato-4'amino-stilbene-2,2'-disulfonic acid).

\section{Acknowledgements}

We thank all blood donors (CF-patients, colleagues and students) and the teams of the "von Pfaundler" station and the "Poliklinik" of the Department of Pediatrics for cooperation. We greatly acknowledge the generous support of Wescor Inc., Logan, UT, USA. This work was supported by the Deutsche Forschungsgemeinschaft SFB 629 (A6).

\section{References}

$\nabla_{1}$ Salhany JM, Schopfer LM, Kay MM, $\boldsymbol{5}_{5}$ Gamble DN, Lawrence C: Differential sensitivity of stilbenedisulfonates in their reaction with band 3 HT (Pro-868$>$ Leu). Proc Natl Acad Sci U S A 1995;92:11844-11848.

-2 Culliford S, Ellory C, Lang HJ, Englert $\mathrm{H}$, Staines H, Wilkins R: Specificity of classical and putative $\mathrm{Cl}(-)$ transport inhibitors on membrane transport pathways in human erythrocytes. Cell Physiol Biochem 2003;13:181-188.

-3 Schwiebert EM, Benos DJ, Egan ME, Stutts MJ, Guggino WB: CFTR is a conductance regulator as well as a chloride channel. Physiol Rev 1999;79:S145S166.

-4 Sprague RS, Ellsworth ML, Stephenson $\mathrm{AH}$, Kleinhenz ME, Lonigro AJ: Deformation-induced ATP release from red blood cells requires CFTR activity. Am J Physiol 1998;275:H1726-H1732.
Verloo P, Kocken CH, Van Der WA, Tilly BC, Hogema BM, Sinaasappel M, Thomas AW, de Jonge HR: Plasmodium falciparum-activated chloride channels are defective in erythrocytes from cystic fibrosis patients. J Biol Chem 2004;279:10316-10322.

Sterling KM, Jr., Shah S, Kim RJ, Johnston NI, Salikhova AY, Abraham EH: Cystic fibrosis transmembrane conductance regulator in human and mouse red blood cell membranes and its interaction with ecto-apyrase. J Cell Biochem 2004;91:1174-1182.

Stumpf A, Wenners-Epping K, Walte M, Lange T., Koch HG, Haeberle J, Duebbers A, Falk S, Kiesel L, Nikova D, Bruns R, Bertram H, Oberleithner H, Schillers H: Physiological concept for a blood based CFTR test. Cell Physiol Biochem 2006; 17:29-36.
Cabantchik ZI and Greger R: Chemical probes for anion transporters of mammalian cell membranes. Am J Physiol 1992;262:C803-C827.

Diakov A, Koch JP, Ducoudret O, MullerBerger S, Fromter E: The disulfonic stilbene DIDS and the marine poison maitotoxin activate the same two types of endogenous cation conductance in the cell membrane of Xenopus laevis oocytes. Pflugers Arch 2001;442:700-708.

Liu L and Chander A: Stilbene disulfonic acids inhibit synexin-mediated membrane aggregation and fusion. Biochim Biophys Acta 1995; 1254:274-282.

Nadif KN, Bultynck G, Parys JB, Callewaert G, Missiaen L, De SH: Suramin and disulfonated stilbene derivatives stimulate the $\mathrm{Ca} 2+$-induced $\mathrm{Ca} 2+$-release mechanism in A7r5 cells. Mol Pharmacol 2005;68:241-250. 
12 Hill AP and Sitsapesan R: DIDS modifies the conductance, gating, and inactivation mechanisms of the cardiac ryanodine receptor. Biophys J 2002;82:3037-3047. Santos FT, Scofano HM, Barrabin H, Meyer-Fernandes JR, Mignaco JA: A novel role of 4,4'diisothiocyanatostilbene-2,2'-disulfonic acid as an activator of the phosphatase activity catalyzed by plasma membrane Ca2+-ATPase. Biochemistry 1999;38:10552-10558.

$>14$ Furukawa T, Virag L, Sawanobori T, Hiraoka M: Stilbene disulfonates block ATP-sensitive $\mathrm{K}+$ channels in guinea pig ventricular myocytes. J Membr Biol 1993;136:289-302.

Maddy AH: A fluorescent label for the outer components of the plasma membrane. Biochim Biophys Acta 1964;88:390-399.

Madeja M, Musshoff U, Kuhlmann D, 26 Speckmann EJ: Membrane currents elicited by the epileptogenic drug pentylenetetrazole in the native oocyte of Xenopus laevis. Brain Res 1991;553:27-32.

17 Schillers H, Danker T, Madeja M Oberleithner $\mathrm{H}$ : Plasma membrane protein clusters appear in CFTRexpressing Xenopus laevis oocytes after cAMP stimulation. J Membr Biol 2001;180:205-212.

Hamill OP, Marty A, Neher E, Sakmann B, Sigworth FJ: Improved patch-clamp techniques for high-resolution current recording from cells and cell-free membrane patches. Pflugers Arch 1981;391:85-100.

Barry PH and Lynch JW: Liquid junction potentials and small cell effects in patchclamp analysis. J Membr Biol 1991;121:101-117.

-20 Horobin RW, Payne JN, Jakobsen P: Histochemical implications of the chemical and biological properties of SITS and some related compounds. J $>30$ Microsc 1987;146 ( Pt 1):87-96.

Mairbaurl H, Schulz S, Hoffman JF: Cation transport and cell volume changes in maturing rat reticulocytes. Am J Physiol Cell Physiol 2000;279:C1621C1630.
22 Duranton C, Huber SM, Lang F: Oxidation induces a $\mathrm{Cl}(-)$-dependent cation conductance in human red blood cells. J Physiol 2002;539:847-855.

Lang PA, Kempe DS, Myssina S, Tanneur V, Birka C, Laufer S, Lang F, Wieder T, Huber SM: $\mathrm{PGE}_{2}$ in the regulation of programmed erythrocyte death. Cell $>32$ Death Differ 2005;12:415-428.

24 Lang F, Lang KS, Wieder T, Myssina S, Birka C, Lang PA, Kaiser S, Kempe D, Duranton C, Huber SM: Cation channels, cell volume and the death of an erythrocyte. Pflugers Arch 2003;447:121-125.

Loussouarn G, Demolombe S, 33 Mohammad-Panah R, Escande D, Baro I: Expression of CFTR controls cAMPdependent activation of epithelial $\mathrm{K}+$ currents. Am J Physiol 1996;271:C1565C1573.

Arniges M, Vazquez E, FernandezFernandez JM, Valverde MA: Swellingactivated $\mathrm{Ca} 2+$ entry via TRPV4 channel is defective in cystic fibrosis airway epithelia. J Biol Chem 2004;279:5406254068.

27 Ruknudin A, Schulze DH, Sullivan SK, Lederer WJ, Welling PA: Novel subunit composition of a renal epithelial KATP channel. J Biol Chem 1998;273:1416514171.

>28 Mall M, Hipper A, Greger R, Kunzelmann >36 K: Wild type but not deltaF508 CFTR inhibits $\mathrm{Na}+$ conductance when coexpressed in Xenopus oocytes. FEBS Lett 1996;381:47-52.

29 Wagner CA, Ott M, Klingel K, Beck S, Melzig J, Friedrich B, Wild KN, Broer S, Moschen I, Albers A, Waldegger S, Tummler B, Egan ME, Geibel JP, Kandolf R, Lang F: Effects of the serine/threonine kinase SGK1 on the epithelial $\mathrm{Na}(+)$ channel $(\mathrm{ENaC})$ and CFTR: implications for cystic fibrosis. Cell Physiol Biochem 2001;11:209-218.

Gabriel SE, Clarke LL, Boucher RC, Stutts MJ: CFTR and outward rectifying chloride channels are distinct proteins with a regulatory relationship. Nature 1993;363:263-268.
Kunzelmann K, Mall M, Briel M, Hipper A, Nitschke R, Ricken S, Greger R: The cystic fibrosis transmembrane conductance regulator attenuates the endogenous $\mathrm{Ca} 2+$ activated $\mathrm{Cl}$ conductance of Xenopus oocytes. Pflugers Arch 1997;435:178-181.

Vennekens R, Trouet D, Vankeerberghen A, Voets T, Cuppens H, Eggermont J, Cassiman JJ, Droogmans G, Nilius B: Inhibition of volume-regulated anion channels by expression of the cystic fibrosis transmembrane conductance regulator. J Physiol 1999;515 ( Pt 1):7585 .

Ogura T, Furukawa T, Toyozaki T, Yamada K, Zheng YJ, Katayama Y, Nakaya $\mathrm{H}$, Inagaki $\mathrm{N}$ : $\mathrm{ClC}-3 \mathrm{~B}$, a novel $\mathrm{ClC}-3$ splicing variant that interacts with EBP50 and facilitates expression of CFTR-regulated ORCC. FASEB J 2002;16:863-865.

Fahlke C: Ion permeation and selectivity in ClC-type chloride channels. Am J Physiol Renal Physiol 2001;280:F748F757.

Shimizu S, Matsuoka Y, Shinohara Y, Yoneda Y, Tsujimoto Y: Essential role of voltage-dependent anion channel in various forms of apoptosis in mammalian cells. J Cell Biol 2001;152:237-250.

Thinnes FP, Hellmann KP, Hellmann T, Merker R, Schwarzer C, Walter G, Gotz $\mathrm{H}$, Hilschmann N: Studies on human porin XXI: gadolinium opens Up cell membrane standing porin channels making way for the osmolytes chloride or taurine-A putative approach to activate the alternate chloride channel in cystic fibrosis. Mol Genet Metab 2000;69:240251 .

Buettner R, Papoutsoglou G, Scemes E, Spray DC, Dermietzel R: Evidence for secretory pathway localization of a voltage-dependent anion channel isoform. Proc Natl Acad Sci U S A 2000;97:3201-3206.

Lange T., Jungmann P, Haberle J, Falk S, Duebbers A, Bruns R, Ebner A, Hinterdorfer P, Oberleithner H, Schillers $\mathrm{H}$ : Reduced number of CFTR molecules in erythrocyte plasma membrane of cystic fibrosis patients. Molecular Membrane Biology 2006;23:1-7. 